\title{
Ética, diálogo entre teoria e prática: por uma ética que nos re-mova e nos co-mova
}

Eva Aparecida Rezende de Moraes

Eu vim para que todos tenham vida e vida em abundância (Jo 10,10b).

Jesus Cristo

Tente mover o mundo - o primeiro passo será mover a si mesmo.

Platão

Aprendi através da experiência amarga a suprema lição: controlar minha ira e torná-la como o calor, que é convertido em energia. Nossa ira controlada pode ser convertida numa força capaz de mover o mundo.

Mahatma Gandhi

O que é ética? Nasce conosco ou é determinada pelo meio em que vivemos? Desde muito tempo, buscamos responder a essas e outras questões afins. As respostas não são óbvias. Algumas linhas filosóficas defendem, a partir da decodificação do genoma, que possuímos um gene da ética, herdado de algum antepassado. Em 14 de janeiro de 2008, Steven Pinker, professor de Psicologia da Universidade de Harvard, escrevia um artigo no New York Times, intitulado "The Moral Instinct: Evolution has endowed us with ethical impulses. Do we know what to do with them?"1 , onde levanta a possibilidade da existência da moralidade genética; pouco antes, em 2006, primatólogos defendiam essa tese, devido à presença de moralidade humana em animais sociais²; Marc D. Hauser, biólogo da Universidade de Harvard, propõe que as pessoas nascem com uma "gramática moral" em seus circuitos neurais, feita pela evolução; Harper Collins, também em 2006, lançava seu livro Moral Minds, onde argumenta que essa "gramática" gera julgamentos morais instantâneos e que são inacessíveis à mente consciente; Robert Wright, em seu livro The Animal Moral, afirma que a moralidade é uma adaptação projetada para maximizar geneticamente o auto-interesse, uma função que é inteiramente escondida da nossa experiência consciente... Assim, segundo esses autores, é preciso reconstruir a moral "de baixo para cima", na esteira de Darwin ${ }^{3}$; psicólogos, sociólogos e outros, ao contrário, nos garantem que a educação ética é mais importante na formação de uma pessoa do que sua genética... Quem está com a razão?

Mas este pequeno artigo não visa tratar disso: o que importa refletir aqui é para onde vamos, que caminhos éticos escolhemos para nossa vida e nossa sociedade. No dia a dia, buscamos organizar "nossa casa", nosso eu, nossos projetos e sonhos, nossas relações; buscamos, constantemente, escolher a melhor resposta frente aos desafios, experimentar, mudar, criar. É uma atividade e necessidade constantes, não particular desse ou daquele

\footnotetext{
${ }^{1}$ Cf. PINKER, Steven. "A Moral Gene. Ethics Blog". In: http://www.ruderfinn.com/blogs/ethics/2008/01/a-moralgene.html .

${ }^{2}$ Cf. "The moral gene". In: http://www.indianexpress.com/news/the-moral-gene/16009/ .

${ }^{3}$ Cf. PINKER, Steven. "Is There a Gene for Compassion?". In:

http://cogweb.ucla.edu/Abstracts/Pinker_on_Wright_94.html.
} 
momento histórico, dessa ou daquela cultura. Assim, a ética é sempre desafiadora e também, e talvez por isso, apaixonante. O autor Nilo Agostini defende, junto a outros autores, a articulação de três elementos fundamentais para uma sociedade saudável: ethos, moral e ética ${ }^{4}$. Segundo ele, existe uma dinâmica entre esses elementos, que interagem nas diversas culturas, na elaboração dos valores e na modelação dos comportamentos humanos. Cada povo, cada cultura, cada sociedade, cada pessoa, articulam esses três elementos, construindo seu modo próprio de habitar um espaço e um tempo, com regras e valores próprios. Para Agostini, o ethos é o fundamento, a base dessa interação; para Fábio Konder Comparato, ética é o conjunto de princípios e valores que norteiam a vida humana - princípios, adverte ele, que são normas de comportamento social (= cujo conjunto chamamos moral) e, não, simples ideais de vida ${ }^{5}$.

Ethos é o alicerce que sustenta o humano; é dinâmico e está na origem das normas comportamentais e da própria diversidade das culturas e religiões ${ }^{6}$. Para os que crêem, é a marca original do Criador impressa nos seres humanos; para os cristãos, Jesus Cristo resgatou este ethos em todo o seu vigor, numa conjugação simultânea e plena do divino e do humano. Ethos, portanto, é parte de nossa transcendência, aquilo que nos faz diferentes dos demais seres vivos; algo que transcende a biologia, a história, a finitude; é aquilo que nos marca, nos identifica. Os filósofos gregos clássicos criaram a palavra ethos e, em sua época, já distinguiam duas grafias e duas fonias: uma utilizava a palavra ethos (com um épsilon) para designar o costume, o comportamento, ou seja, a exterioridade de uma pessoa ou povo; outra era aethos (com a letra grega eta), e indicava moradia, lar, o lugar do seu eu, ou seja, o caráter, aquilo que somos, marcando, assim, a interioridade de uma pessoa ou povo.

Já a partir daqui, encontramos um desafio: o que nos define é o que somos ou o que fazemos? Em nossos juízos morais (dos fatos, de nós mesmos, dos outros, das sociedades, das culturas, das religiões), analisamos, geralmente, as atitudes ou a essência das pessoas? Como aprofundar nosso olhar crítico para aquilo que os outros realmente são? Como articular minhas atitudes pessoais com aquilo que realmente sou, aquilo que me move, me impulsiona? Cada espécie em nosso planeta - e não somente a Homo sapiens sapiens ${ }^{7}$ - se define pelo que é e pelo que faz - é o que argumenta o autor Mário Antônio Sanches ${ }^{8}$ (observe que ele usa a partícula "e" e, não, "ou"). A coerência entre o que se é e o que se faz é observada na maioria dos animais; entretanto, apenas o ser humano reflete sobre o que pode e o que deve

\footnotetext{
${ }^{4}$ Cf. AGOSTINI, Nilo. Ética e Evangelização. A dinâmica da alteridade na recriação da moral. Petrópolis: Vozes. 1994. P. 21ss.

${ }^{5}$ Cf. COMPARATO, Fábio Konder. Ética. Direito, Moral e Religião no mundo moderno. São Paulo: Companhia das Letras. $2006^{2}$. P. 494ss.

${ }^{6}$ Cf. AGOSTINI, Nilo. Ética e Evangelização, op. Cit., p. 22.

7 Atualmente, essa é a nossa classificação: nós, seres humanos, somos classificados como "sapiens sapiens", ou seja, duplamente sábio. Nota da Autora.

${ }^{8}$ Cf. SANCHES, Mário Antônio. Bioética. Ciência e transcendência. São Paulo: Edições Loyola. 2004. P. 9.
} 
fazer. Não agimos simplesmente de acordo com o que somos, nem nos definimos necessariamente pelo que fazemos: somos capazes de dissociar essas duas realidades e criar uma terceira - a esfera da decisão e do planejamento que direciona a ação. Diz Sanches que, se uma determinada ação não condiz com o que se espera eticamente de um ser humano, algum problema está acontecendo, e pode estar localizado na ação em si (que contradiz a realidade humana), ou na percepção do que significa ser humano. Assim, decidir sobre o que deve ser feito implica, também, uma decisão sobre sua própria identidade, forjando-a, recriando-a, revendo-a.

Para autores, como Nilo Agostini e T. Goggi, somente captamos o ethos de uma pessoa ou de um grupo ou de um povo, quando nos colocamos à escuta, quando perscrutamos as suas motivações e intenções profundas, o sentido de seus gestos e ações no interior de seu mundo cultural e existencial, nem sempre verbalizados ${ }^{9}$. Existiriam quatro caminhos que podem nos ajudar nessa tarefa: a adaptação (executar papeis ou funções dentro do mesmo grupo), a associação (captar elementos que atingem, desde os hábitos alimentares, até as relações sociais entre castas, raças e povos, incluindo, aqui, os preconceitos e estereótipos), a interpretação (explicar as expressões de sentido - como mitos, símbolos, crenças, artes, religiões,...) e o pensar (processo de afastamento e ruptura daquilo que é óbvio e captação da significação profunda das coisas e das pessoas). A articulação entre esses passos (ou caminhos, acima descritos) é dialética, dinâmica e simultânea: os passos não se dão de forma linear, mas envolvente. Estamos, o tempo todo, nos adaptando, associando, interpretando, fazendo e refazendo, captando o significado profundo.

Esse exercício (o esforço por captar a essência das pessoas e, não apenas, analisar suas ações) nos ajuda a re-mover e co-mover na direção de uma ética saudável. A palavra mover vem do latim - movo, movere - e possui vários significados na língua portuguesa: pôrse em movimento, agitar-se ${ }^{10}$; dar, executar ou ganhar movimento; mudar de lugar; desencadear, promover, suscitar, provocar ou ter determinada emoção; andar em torno de um eixo ou um centro; ou induzir, persuadir, lançar ação judicial contra alguém; desenvolver teorias e sonhos (como "mover montanhas"). Re-mover tem, assim, o significado de fazer mudar de lugar $^{11}$; de forma figurativa, pode ser usado como sinônimo de comover, inspirar dó ou compaixão - entretanto, co-mover (com destaque no prefixo "co") significa se mover com alguém, ou por alguém. Uma ética que re-mova e co-mova é uma ética analética - o termo é esse mesmo: analética! Para Feuerbach, isto significa partir do diálogo do Outro, é um saberouvir, colocar-se num "face a face" ante o Outro, para que ele se revele, nos deixando

\footnotetext{
${ }^{9}$ Cf. GOFFI, T. Ethos Popolare. Brescia: Editrice Queriniana, 1979, P. 11s. Apud ibidem, p. 25.

${ }^{10}$ Cf. http://www.priberam.pt/dlpo/mover.

${ }^{11}$ Cf. http://www.dicio.com.br/mover/.
} 
interpelar, nos deixando provocar ${ }^{12}$. É, segundo o autor, a única forma de não nos vermos como totalidade - ou como a única totalidade - que é a máxima do subjetivismo. O segundo passo é nos colocarmos a serviço do Outro: um saber-servir - ou seja, não basta saber dialogar e ser inteligente nas argumentações: é necessário, também, ser justo e ser bom! Somente diante da justiça e da bondade, a voz dos sem voz irrompe, evitando que a totalidade que cada pessoa é se feche em si mesma. Isso nos salva, eticamente falando: fechar-se sobre sua própria totalidade é um suicídio existencial.

A Conferência Nacional dos Bispos do Brasil (CNBB) nos conclama a desenvolver uma ética plenamente humana e que atenda às exigências éticas do Evangelho de Jesus Cristo $^{13}$. Esses dois eixos basilares, segundo o Documento, nos ajudariam a renovar a pessoa humana e nossa sociedade; a focar a ética na defesa da dignidade humana e dos ecossistemas; a superar a distância entre ética pública e ética privada; a superar o abismo entre a realização pessoal e a responsabilidade pelo bem comum. O Documento alerta que não são dois caminhos, duas éticas às quais podemos optar, mas um único projeto, que englobe a renovação pessoal e social - ao mesmo tempo. Na esfera pública (ou política), o caminho seria uma ética iluminada pelos princípios da solidariedade e da participação ${ }^{14}$. A vida política deverá reencontrar sua dignidade na edificação da cidade humana, onde todos tenham oportunidade de realização pessoal e de comunhão solidária; um dos pilares principais dessa edificação cidadã é promover uma ordem econômica social e política com as bases de uma economia solidária, real e eficiente ${ }^{15}$, combatendo o individualismo e o corporativismo. A ética não deve ser "mercadocêntrica", e a modernização científica e tecnológica não pode reduzir a pessoa humana a mera "mercadoria" ou "instrumento útil. Essa ética "do bem comum" deverá valorizar a informação e seus meios, mas, também, visar sua democratização e uma educação do consumo e para o senso crítico.

A ética é uma construção ampla em nós, de muitos elos "articuladores", o que se apreende ser necessário não dissociar nossa formação pessoal de valores e princípios de nossa ação comportamental: devemos ser o que fazemos, e fazer o que somos. Muitos desvios acontecidos em nossa sociedade existem por falta de formação ética da parte de muitos de nossos profissionais - são bons técnicos e competentes em diversas áreas, mas faltos de valores éticos fundamentais, que privilegiem o serviço ao bem comum, o diálogo, a partilha, a verdade, a felicidade. São esses e outros valores éticos que aprendemos em nosso berço: a

\footnotetext{
${ }^{12}$ Cf. Apud AGOSTINI, Nilo. Ética e Evangelização, op. Cit., p. 27-28.

${ }^{13}$ Cf. DOCUMENTO no 50 DA CNBB. São Paulo: Paulinas. 1993. P. 87-90.

${ }^{14}$ Poderíamos acrescentar, aqui, o princípio da subsidiariedade. Esse princípio "pretende assegurar uma tomada de decisões tão próxima quanto possível do cidadão, mediante a verificação constante de que a ação a empreender a nível comunitário se justifica relativamente às possibilidades oferecidas pelo nível nacional, regional ou local.(...) Este princípio está intimamente relacionado com os princípios da proporcionalidade e da necessidade...". http://www.dicionarioinformal.com.br/subsidiariedade/ . Nota da autora.

${ }^{15}$ Cf. DOCUMENTO DA CONFERÊNCIA EPISCOPAL LATINO-AMERICANA DE SANTO DOMINGO. №s $296 ; 201$. Apud ibidem, p. 88.
} 
família e os primeiros grupos humanos dos quais participamos. Evidentemente, os meios de comunicação de massa e a globalização têm interferido nessa formação ética inicial, algo que não é, de forma imediata, danoso ou ruim. O choque de valores culturais, religiosos, familiares, tradicionais (= instituídos) e novos (= instituintes) deve vir acompanhado de diálogo e respeito mútuo: nem tudo o que é novo é ruim e nem tudo o que é do passado é bom; e, igualmente, nem tudo o que é novo é bom e nem tudo o que é do passado é ruim - cabe a cada um e a toda a sociedade, desde a família até as grandes instituições e associações públicas e privadas, um esforço para o fim do preconceito e a quebra de estereótipos, que mais atrapalham do que ajudam. O diálogo franco, o respeito ao pensamento diferente e o coração aberto são elementos fundamentais para esse exercício ético.

\section{Para refletir:}

1. Como vimos acima, alguns autores atuais defendem que a ética deve ser desenvolvida "de baixo para cima" - ou seja, partindo da genética do indivíduo até atingir seu ambiente; outros, por sua vez, defendem que a maior influência (ou educação) ética deve ser feita "de cima para baixo" - ou seja: partindo do ambiente até chegar à genética do indivíduo. O que você pensa a esse respeito?

2. Parafraseamos, acima, Platão: "Tente mover o mundo - o primeiro passo será mover a si mesmo". Então: como vencer, em nós, o forte individualismo moderno, que nos instala e nos acomoda e que nos impede de nos re-mover e co-mover diante da situação concreta do outro?

\section{Bibliografia:}

AGOSTINI, Nilo. Ética e Evangelização. A dinâmica da alteridade na recriação da moral. Petrópolis: Vozes. 1994.

COMPARATO, Fábio Konder. Ética. Direito, Moral e Religião no mundo moderno. São Paulo: Companhia das Letras. $2006^{2}$.

DOCUMENTO DA CONFERÊNCIA EPISCOPAL LATINO-AMERICANA DE SANTO DOMINGO. DOCUMENTO no 50 DA CNBB. Pessoa e Sociedade. São Paulo: Paulinas. 1993.

GOFFI, T. Ethos Popolare. Brescia: Editrice Queriniana, 1979.

SANCHES, Mário Antônio. Bioética. Ciência e transcendência. São Paulo: Edições Loyola.2004.

\section{Webliografia:}

PINKER, Steven. "A Moral Gene. Ethics Blog". In: http://www.ruderfinn.com/blogs/ethics/2008/01/a-moral-gene.html . . "Is There a Gene for Compassion?". In: http://cogweb.ucla.edu/Abstracts/Pinker_on_Wright_94.html .

"The moral gene". In: http://www.indianexpress.com/news/the-moral-gene/16009/ . http://www.priberam.pt/dlpo/mover.

http://www.dicio.com.br/mover/. 